\title{
The Effect of Prohibiting Deal Protection in Mergers and Acquisitions: Evidence from the United Kingdom
}

\section{Citation}

Restrepo, Fernán, and Guhan Subramanian. "The Effect of Prohibiting Deal Protection on M\&A Activity: Evidence from the United Kingdom." Journal of Law \& Economics 60, no. 1 (February 2017): 75-113.

\section{Published Version}

https://www.journals.uchicago.edu/doi/abs/10.1086/692585

\section{Permanent link}

http://nrs.harvard.edu/urn-3:HUL.InstRepos:40549572

\section{Terms of Use}

This article was downloaded from Harvard University's DASH repository, and is made available under the terms and conditions applicable to Open Access Policy Articles, as set forth at http:// nrs.harvard.edu/urn-3:HUL.InstRepos:dash.current.terms-of-use\#OAP

\section{Share Your Story}

The Harvard community has made this article openly available.

Please share how this access benefits you. Submit a story.

\section{Accessibility}




\title{
The Effect of Prohibiting Deal Protection in M\&A: Evidence from the United Kingdom
}

\author{
Fernán Restrepo* \\ Guhan Subramanian $^{* *}$
}

\begin{abstract}
Since 2011, the U.K. has prohibited all deal protections - including termination fees - in M\&A deals. Prior to 2011, the U.K. permitted termination fees up to $1 \%$ of deal value and there was no prohibition on other protection devices. We examine the effect of this regulatory change on deal volumes, the incidence of competing offers, deal jumping rates, deal premiums, and completion rates in the U.K., relative to the other European G-10 countries. We find that $M \& A$ deal volumes in the U.K. declined significantly in the aftermath of the 2011 Reforms, relative to deal volumes in the European G-10 countries. We find no countervailing benefits to target shareholders in the form of higher deal premiums or more competing bids. Completion rates and deal jumping rates also remained unchanged. We estimate that the incidence-rate ratio of U.K. deals to non-UK deals after the reform was approximately 50\% the incidence-rate ratio of U.K. deals to non-U.K. deals prior to the reform. In addition, we estimate USD 19.3 billion in lost deal volumes per quarter in the U.K. relative to the control group due to the 2011 Reforms, implying a quarterly loss of USD3.2 billion for shareholders of U.K. companies. Our results suggest that deal protections provide an important social welfare benefit by facilitating the initiation of $M \& A$ deals.
\end{abstract}

\footnotetext{
*Stanford Law School. Email: fernanr@stanford.edu

** Harvard Law School and Harvard Business School. Email: gsubramanian@hbs.edu. Fernán gratefully acknowledges financial support from the John M. Olin Program in Law and Economics and the Gregory Terrill Cox Fund at Stanford Law School.
} 


\section{The Effect of Prohibiting Deal Protection in M\&A: Evidence from the United Kingdom}

\section{Introduction}

Since September 2011, the United Kingdom has prohibited all deal protections including termination fees - in acquisitions of U.K. public companies (hereinafter, the "2011 Reforms" or the "2011 Reform"). In contrast, for the twelve-year period from 1999 to 2011 , the U.K. permitted termination fees up to $1 \%$ of deal value and there was no restriction on other deal protection devices. This regulatory change presents the opportunity for a natural experiment: what happened to deal volumes, the incidence of competing offers, deal jumping, deal premiums, and deal completion rates in the U.K. M\&A marketplace after the 2011 Reforms? To our knowledge, this paper presents the first investigation of these questions. The results permit an assessment of the 2011 Reforms, and also shed light on the social welfare implications of deal protection in M\&A markets more generally.

Using a database of public-company M\&A deals in the U.K. and a control group of other European G-10 countries over the period 2000-2015, we find that the incidence of deal volumes in the U.K. decreased approximately 50\% after the 2011 Reforms, relative to the control group. The incidence of competing offers, deal jumping rates, deal premiums, and deal completion rates for first bidders did not change. In terms of dollar value, we estimate that U.K. shareholders have lost USD19.3 billion per quarter through deterred M\&A deals in the five years after the 2011 Reforms. In sensitivity analyses, we obtain estimations that are directionally and statistically consistent with these results if we use the U.S. as a control group instead of using the control group of European G-10 economies.

Taken together, the results indicate that deal protections provide an important social welfare benefit by facilitating the initiation of M\&A deals, and that the loss in shareholder value from reduced deal volumes in the U.K. was not offset by higher bidding competition or deal premiums.

The remainder of this article proceeds as follows. Part 2 reviews the motivation for deal protection devices, provides relevant background on the U.K. takeover marketplace and the takeover law of the control group, reviews the prior literature, and describes the 2011

Reform. Part 3 describes our methodology and data. Part 4 presents our results. Part 5 discusses the findings. Part 6 concludes.

\section{Background}

\subsection{Motivation for termination fees}

In any public-company acquisition, the need for shareholder and regulatory approvals creates a window between the date of the deal signing/announcement and the date that the acquirer can close the deal. This window, which is approximately three months on average, introduces the possibility that a higher-value bid will emerge between the 
signing and the closing. Because the target board's fiduciary duty typically requires consideration of any such higher offer, the acquirer cannot eliminate this risk through contracting with the target. Instead, the typical solution in public-company M\&A is "deal protection" (equivalently, a "lockup agreement") which provides value to the first bidder in the event that the target board accepts a higher-value bid. Coates and Subramanian (2000) define a deal protection device as "a term in an agreement related to an M\&A transaction involving a public company target that provides value to the bidder in the event that the transaction is not consummated due to specified conditions."

Deal protections can have two main effects in the M\&A marketplace: first, they can encourage a first bidder to bid, by compensating that bidder for (e.g.) opportunity costs, reputational costs, and out-of-pocket expenses; and second, they can discourage second bidders from bidding, because they siphon value out of the target company for the firstbidder's benefit, in the event an overbid. These two effects have directionally opposite implications for overall social welfare. The ex ante inducement effect for first bidders promotes value-enhancing deals; but the ex post deterrent effect for second bidders discourages potential overbids that would increase target shareholder returns and increase allocational efficiency in the M\&A marketplace.

\subsection{Comparison of U.K., E.U., and U.S. deal protection regimes}

In the 1980s and 1990s, three main types of deal protection emerged: asset lockups, which gave the acquirer the right to buy certain assets at a specified price in the event of an overbid (typically, at a price lower than fair market value); stock option lockups, which gave the acquirer the right to buy the shares of the target company (typically, due to stock exchange constraints, 19.9\%) at a specified price (typically the deal price); and termination fees (or equivalently, "breakup fees" or "break fees"), which gave the acquirer the right to receive a cash amount from the target in the event that the target accepted a superior offer.

These deal protections have been used particularly in the U.S. Asset lockups were used until the mid-1980s; but after the Delaware Supreme Court struck down asset lockups in Revlon ${ }^{1}$ and Macmillan ${ }^{2}$ they disappeared for thirty years, until the JPM-Bear Stearns deal in 2008. (Restrepo and Subramanian 2017) Stock option lockups were commonplace until the elimination of pooling accounting in 2001. The reason is that exercise of a stock option would "queer" pooling for a third-party bidder, thus discouraging third-party bids. Once pooling accounting was eliminated the need to queer pooling for a third-party bidder disappeared, and stock option lockups correspondingly went away. By the late 1990s and continuing to present day, by far the most common deal protection tool of choice in the U.S. is the termination fee.

In the U.K., deal protection of any kind was uncommon throughout the 1990s, potentially because practitioners viewed it as a type of "frustrating action" that would be barred by the U.K. Takeover Code. (Coates 2009) In 1999, the Takeover Panel approved

\footnotetext{
${ }^{1}$ Revlon v. MacAndrews \& Forbes Holdings, 506 A.2d 173, 183 (Del. 1986).

${ }^{2}$ Mills Acquisition Co. v. Macmillan, Inc., 559 A.2d 1261, 1286-87 (Del. 1989).
} 
termination fees up to $1 \%$, implicitly endorsing termination fees up to this amount, and other deal protection devices emerged during the 2000s (Takeover Panel, 2010a). But in 2011, the same Takeover Panel prohibited all deal protections (with some minor exceptions), including termination fees. Therefore, the U.K. deal protection regime included protection devices from 1999 to 2011 but not before or after. The exogenous shock to the deal protection regime provides the motivation for our empirical test. ${ }^{3}$

Other western European countries take a middle ground between the tolerant deal protection regime of the U.S. and the categorical prohibition on deal protections in the U.K. In general, other western European countries permit termination fees, but typically subject to constraints: e.g., they may only compensate the acquirer for its out-of-pocket costs; they must be in the target shareholders' best interests; and (as in the U.S.) they must comply with the target board's fiduciary duties and must not unduly tilt the playing field against prospective third-party bidders. Clifford Chance summarizes the different European regimes as follows:

It is not market practice to find break fees on M\&A transactions in France, Germany, Hungary, Ukraine, Belgium, and Luxembourg. In France, a target may agree to a break fee with a white knight on a hostile bid and, although while rare, if agreed, break fees do not generally exceed $2 \%$ of the deal value. In the Netherlands and Spain, break fees are used and are typically limited to $1 \%$ of deal value.

Table 1 provides a summary of the deal protection regimes in the U.K., the other European G-10 economies that form the baseline control group, and the U.S. As shown, most of the other European G-10 countries are closer to the post-2011 approach in the U.K., which effectively prohibits deal protections. For purposes of our empirical test, the critical point is that the deal protection regime (both the law "on the books" and the law as applied) has not changed in these other countries either before or after the 2011 Reforms.

\subsection{Literature review}

There is a large theoretical and empirical literature on deal protection. In the realm of theory, Schwartz (1986) proposes a ban on termination fees and other deal protections, in order to encourage competition. Ayres (1990), and Fraidin and Hanson (1994) present theoretical models showing that, under certain assumptions, deal protection should not reduce allocational efficiency in the M\&A marketplace; as a result, they propose a more tolerant view of deal protections. Bainbridge (1990) similarly proposes a bright-line rule that deal protection should be limited to $10 \%$ of the overall deal value.

Coates and Subramanian (2000) present a model that incorporates several real-world factors. When these factors are considered, Coates and Subramanian show that allocational efficiency can be reduced through deal protection. The authors then present the first empirical evidence on U.S. deal protections, which is consistent with their

\footnotetext{
${ }^{3}$ We focus, however, on the 2011 regulatory change because there was no clear rule before 1999.
} 
predictions. Subsequent empirical work (e.g., Burch (2001), Bates and Lemmon (2003), and Officer (2003)) further confirms these findings, with respect to U.S. M\&A deals.

Among other results, Subramanian and Coates (2000) find a strong correlation between breakup fees and completion rates for first bidders. Burch (2001) finds that stock lockups inhibit competition but that they are associated with higher target announcement returns. Bates and Lemmon (2003) find that breakup fees are associated with higher deal completion rates and greater premiums. Similarly, Officer (2003) finds that termination fees are associated with higher success rates and premiums, and finds only weak support for the notion that termination fees deter competing bids. None of these works exploit an exogenous shock to the termination fee regime or an event comparable to the 2011 Reform to examine whether there is a causal relationship between termination fees (or a general prohibition of protection devices) and deal volumes, deal competition, premiums or completion rates.

To our knowledge, there are two prior papers examining differences in deal volumes between the U.S. and U.K. These papers are closest to our current work though both papers predate the 2011 Reforms. Rossi and Volpin (2004) find that $66 \%$ of U.S.-listed firms were acquired during the period 1990-1999, compared to only 54\% of U.K. listed firms. Coates (2010) similarly finds that the overall bid incidence rate in the U.K. from 1990 to 2008 was $77 \%$ of the U.S. rate. Coates concludes that "[w]hile many other factors may contribute to this difference, a lower bid incidence rate in the United Kingdom is consistent with the finding ... that break fee law inhibits some bids that might otherwise occur if the target were free to provide an initial bidder with insurance against the risk of competition." (Coates, 2010, 263) Coates also finds that termination fees in U.K. deals clustered around the $1 \%$ limit after such fees were legitimized by the Takeover Panel in 1999.

In the immediate aftermath of the 2011 Reforms, Saulsbury (2012) provided an overview of the differences between U.S. and U.K. deal protection doctrines, and predicted that "the availability of takeover defenses and deal protection devices under Delaware corporate law gives directors of U.S. target companies more negotiating power and allows them to generate higher premiums for shareholders in M\&A transactions compared to their colleagues in the U.K."

More generally, there is a large literature comparing the U.S. and the U.K. on the spectrum between shareholder-friendly and management-friendly corporate law rules. (See, e.g., Gelter 2009; Skeel, 2006). Strine (2016) makes a persuasive case that while the "law on the books" may be more shareholder-friendly in the U.K. relative to the U.S., the law as applied is not. On the specific question of deal protection, we quote the paper at some length because Strine describes the hypothesis that motivates our empirical test:

These deal protections [in the U.S.] provide some comfort to corporations that if they take the high-stakes risk of a public M\&A deal, they will get some protection, if, as can happen, another buyer ends up getting the deal, the regulators say no, or the seller's stockholders choose not to accept the 
offer. This comfort, many think, encourages more value-maximizing deals, to the benefit of stockholders. By contrast, the EU system is not set up to facilitate the voluntary exploration of M\&A transactions. If a strategic competitor wishes to explore a friendly transaction in the EU with an industry rival, it will not only know that its competitors are likely to get access to the same due diligence, but it will know that it is unlikely to be able to receive any compensation if the deal is not consummated. . . . This reality might be thought to deter bidders from making a bid, because the bidder is not only limited from raising its bid, the bidder knows that it will not be reimbursed for the high costs of pursuing the transaction if the bid is not successful. (Strine 2016, 75-76)

Despite these predictions in the previous literature, there is no empirical evidence on the causal effect of the U.K./E.U. approach to protection devices, and particularly on the causal effect of the 2011 Reform. More generally, as mentioned above, there is no empirical work (even in the U.S.) exploiting a natural experiment to test the effect of a general prohibition of deal protection devices on deal volumes, bidding competition, deal jumping, deal premiums, and completion rates. This work therefore not only makes an assessment of the 2011 Reform in particular, but also contributes in a more general way to the literature on the social welfare implications of deal protection in M\&A.

\subsection{Overview of the 2011 Reforms}

The United Kingdom takeover regime changed significantly after September 19, 2011, when the reform to the Takeover Code formally proposed in March 2011 by the Code Committee of the Takeover Panel (the "Code Committee") and subsequently adopted in July 2011 entered into force.

The Code Committee announced the initiation of a consultation process to review the Takeover Code on February 24, 2010, following the takeover of Cadbury plc by Kraft Foots Inc., in the first quarter of 2010, which generated "widespread commentary and public discussion" of the regime governing takeover bids (Takeover Panel, 2011a). On June 1, 2010, the Code Committee invited suggestions for possible amendments to the Code in a public consultation paper ("PCP 2010/2"), which, however, did not set out any specific proposals.

As part of PCP 2010/2, the Code Committee identified several protection devices that appeared to be "typical" in transactional practice. In addition to termination fees, these devices included: (i) "exclusive inducement fee arrangements" (provisions restricting the board of the target company from agreeing to termination fees with competing bidders); (ii) "exclusive implementation agreement arrangements" (provisions restricting the board of the target company from agreeing to a subsequent "implementation agreement" with a

\footnotetext{
${ }^{4}$ Implementation agreements are typically a side contract in transactions executed as schemes of arrangement (a court-approved merger), which impose contractual obligations on the target to ensure that the scheme is conducted diligently. More specifically, scheme of arrangements are court processes in which the target proposes to its shareholders a transaction, the court convenes the shareholder meeting, and then the target shareholders vote to approve or reject the deal. If approved, the court reviews and
} 
competing bidder); (iii) "non-solicitation undertakings" (provisions that restrict the target's board from soliciting competing offers, also known as non-shop provisions); (iv) "notification undertakings" (provisions that require the target board to inform the original buyer of competing bids, the identity of the bidder and the terms of the bid, also known as information rights); (v) "notification undertakings coupled with a restriction on the offeree board from changing its recommendation for a fixed period of time" (provisions that include information rights and additionally prevent the target board from changing its recommendation for a fixed period of time after notifying the original buyer of the competing bid); (vi) "matching rights" (provisions that allow the original buyer to match or improve a competing bid); (vii) "no information undertakings" (provisions that limit the information that the target board can give to a competing bidder or that require that any new information given to the competing bidder be also given to the first bidder); (viii) "force the vote provisions" (provisions in the context of a scheme of arrangement, which force the target board to call a shareholder meeting to consider the original buyer's proposal, even if the target board withdrew its recommendation or recommended a competing bid); (ix) "shareholder direction resolutions" (provisions in the context of schemes of arrangement that force the target board to submit for consideration a special resolution in the shareholder meeting, which, if approved, would require the board to disregard any competing offer made after the meeting and prior to the effective date of the scheme $\mathrm{e}^{5}$ ); and (x) "no piggy-backing undertakings" (provisions that prevent the target board from amending the original bidder's scheme of arrangement, particularly if the amendment allows a competing bidder to use the original bidder's court timetable and process ${ }^{6}$ ).

The consultation period ended on July 27, 2010, which gave rise to a response by the Code Committee on October 21, 2010 in the form of a Statement ("Statement 2010/22"). The Statement presented the Code Committee's conclusions, which included the suggestion of amending the Code to (i) require potential buyers to "clarify their position within a short period of time"; (ii) prohibit deal protection devices; (iii) increase the disclosures that buyers have to make; and (iv) give more importance to the opinion of the target's employees on the transaction.

\footnotetext{
"sanctions" the vote. Because the buyer is not a party to this process, he can use implementation agreements to retain some control over the process. These agreements can involve, for example, the imposition of a timetable on the target and the imposition of certain "conduct of business" restrictions during the court process. In addition, implementation agreements can also include reciprocal obligations, like, for example, the promise (made to the court) that the parties will be bound by the terms of the scheme (which ensures that the target shareholders will receive the stipulated consideration) and the obligation to waive certain conditions prior to the court hearing that sanctions the scheme (which accelerates the process). Implementation agreements can also take place in "contractual offers" (tender offers). In this case, the agreements are used especially when the buyer wants to retain the option to switch from the tender offer to a scheme of arrangement during the course of the transaction or when the target wants to impose obligations on the buyer regarding the satisfaction of conditions related to regulatory approvals. The Takeover Panel did not raise concerns about implementation agreements per se in PCP 2010/2 - only about the deal protection measures that are included in those agreements. See Takeover Panel (2010a).

${ }^{5}$ These provisions are rather uncommon, according to the Takeover Panel (2010a).

${ }^{6}$ Piggy-backing provisions are relevant particularly if there is a risk that a competing bidder will intend to propose to the target shareholders an alternative scheme of arrangement at the same time and as part of the same process as the original bidder's scheme of arrangement, which would therefore allow the competing bidder to use the original bidder's court process to expedite the transaction.

${ }^{7}$ In this document, the Code Committee actually recognized that most of the participants that responded to PCP 2010/2 agreed with allowing breakup fees, but the Committee nonetheless decided to recommend their
} 
On March 21, 2011, the Code Committee published a consultation paper ("PCP 2011/1") with a detailed description of the amendments to the Takeover Code that would implement the conclusions of Statement 2010/22 and invited comments on the proposed amendments. The consultation period for PCP 2011/1 ended on May 27, 2011, and after reviewing the responses from third parties, ${ }^{8}$ the Code Committee formally adopted on July 21, 2011 the reforms proposed in PCP 2011/1. These reforms were published in Response Statement 2011/1 ("RS 2011/1") and Instrument 2011/2, and, as mentioned, entered into force on September 19, 2011.

In its final version, the reform generally prohibited deal protection devices in takeover transactions, including termination fees and the other protection devices identified in PCP 2010/2. The only exceptions to this rule are formal sale processes initiated by the target company and breakup fees in favor of white knights (provided, however, that a hostile offer has already been made, the white knight announced a firm intention to make an offer, and the fee does not exceed $1 \%$ of the deal value). The restriction on protection devices only applies to the target, in the sense that it does not generally prevent the buyer from offering deal protection measures (including reverse termination fees).

In addition to prohibiting deal protection devices, the Takeover Panel also prohibited side commercial agreements that have a deal protection effect and that are signed as part or in connection with the merger. These agreements include particularly contracts under which the target agrees to sell certain assets to the buyer, licensing agreements in favor of the buyer, and financing extended by the buyer to the target. ${ }^{9}$ According to the Takeover Panel, agreements of this nature deter competing bids and therefore are detrimental to the target company. ${ }^{10}$

prohibition. According to the Code Committee: "A majority of the responses to the question of whether the Panel should prohibit or otherwise restrict deal protection measures were in favour of intervention by the Panel in this area. However, the majority of respondents agreed with the Panel's current approach of permitting inducement fees provided that, among other things, the inducement fee is de minimis (which will normally mean no more than $1 \%$ of the value of the offeree company calculated by reference to the offer price). After considering the responses, and notwithstanding the support expressed for the Panel's current approach to inducement fees, the Code Committee intends to propose that the Code should be amended to prohibit deal protection measures and inducement fees (other than in certain limited cases) ..." (Statement 2010/22, 13-14).

${ }^{8}$ Here again, the comments submitted by third parties included opposition to the elimination of termination fees. In the words of the Code Committee, "Respondents were broadly supportive of the proposed amendments to the Code. However, there were significant conflicts of views in relation to certain proposals, including: (a) the proposed requirements for potential offerors to be identified at the start of an offer period and for potential offerors, within 28 days of their being identified, to 'put up or shut up' or obtain a deadline extension; and (b) the proposed prohibition on inducement fees and other offer-related arrangements." (Takeover Panel, 2011a, 4)

${ }^{9}$ The Takeover Panel explicitly clarified, however, that this general prohibition only applies to agreements that are related or that are a consequence of the merger, but not to agreements entered into by the parties in the ordinary course of their businesses. In this sense, if the parties can convince the Takeover Panel that the proposed agreement would have been signed, on the same terms, in the absence of the merger, the Takeover Panel will accept the agreement. See Takeover Panel (2011a).

${ }^{10}$ For a more detailed analysis of the protective effect of side commercial agreements like those mentioned in PCP 2011/1 and the policy implications of those effects, see Restrepo and Subramanian (2017). 
The reform also required that in cases in which the offer period ${ }^{11}$ starts with an announcement by the target company, the target must identify all the potential bidders, including in particular those with which the target is negotiating and those that have unilaterally approached it. In addition, at the start of the offer period, there is an automatic "put up or shut up" ("PUSU") period, which requires that potential bidders clarify their intentions within 28 days from the date they are identified as bidders (that is, they must either announce a firm intention to make an offer or that they will not make one). In addition, the reform increased the disclosure obligations of the buyer with respect to offer-related financing arrangements, adviser's fees, and the buyer's plans for the target.

Following the discussion in Part 2 above, we hypothesize that, by eliminating deal protection devices, the 2011 Reform deterred potential bidders from making offers and therefore deal activity in the United Kingdom declined significantly after that year relative to a control group of relatively similar jurisdictions. ${ }^{12}$ In addition, we examine the effect of the reform on bidding competition, jumping rates, premiums, and deal completion rates. We examine these aspects in the following sections.

\section{Data and methodology}

To test whether the 2011 reform to the U.K. Takeover Code had any effect on deal activity, we constructed a panel consisting of quarterly data on mergers and acquisitions in the United Kingdom and a control group constituted by the rest of G-10 economies in Europe (Belgium, France, Germany, Italy, the Netherlands, Sweden, and Switzerland). We chose these countries as the baseline control group because they are the closest peers available based on two criteria: regional proximity and economic comparability. In sensitivity analyses, however, we also ran the regressions using the U.S. as the control group. To construct the panel, we used all deals announced between January 1, 2000 and December 31, 2015 in the relevant countries, and then aggregated the data at the quartercountry level (particularly for the purposes of the analysis of deal volumes). ${ }^{13}$

\footnotetext{
${ }^{11}$ According to the Takeover Code, the offer period is the period that starts when the first announcement of an offer or possible offer for a company is made, or when certain other announcements are made. These include the announcement that the company is seeking a buyer of $30 \%$ or more of the voting rights or the announcement that the company's board is seeking potential bidders. An offer period ends when the offer becomes unconditional, a scheme of arrangement becomes effective, or all announced offers have been withdrawn or have expired.

12 This possibility was also raised by some of the parties that submitted commentary to the Takeover Panel during the consultation process. As noted by the Code Committee: "Around two-thirds of the respondents who commented on the proposed general prohibition of offer-related arrangements supported it or took a neutral stance. The principal concerns of the remaining third were, in summary, as follows: (...) (b) that a prohibition on inducement fees would be likely to deter potential offerors from making offers, to the potential detriment of shareholders in companies subject to the Code." (Takeover Panel, 2011b, 38).

${ }^{13}$ Ideally, we would use the more granular data at the transaction level and run the difference-in-differences analysis at that level. However, we do not have a type of transaction that was not affected by the reform, that is similar enough to the transactions that were affected, and for which we have data to make a meaningful comparison. In the absence of a more granular control group, therefore, we rely on quarter-
} 
Using this dataset, we employed a difference-in-differences methodology in the framework of a random effects Poisson regression model. We used a Poisson model because the dependent variable is a non-negative integer (the number of deals in each country by quarter) and relied on a random effects framework to account for withincountry correlation. In addition, to account for over-dispersion in the dependent variable, we also ran the regressions using a random effects negative binomial model. We also estimated hierarchical models in sensitivity analyses, which allowed for a random intercept and random slopes for the variables that vary within countries. ${ }^{14}$

The independent variables in the regression include a treatment variable ("UK") that takes the value of one for the United Kingdom and zero otherwise; a time variable ("PostReform") that takes the value of one for observations after the first quarter of 2011 (including that quarter) and zero otherwise; and an interaction between these two variables ("UK $\times$ Post-Reform"), which yields the estimator of difference-in-differences. If the absence of deal protection devices deters prospective bidders (and, therefore, the incidence of deals in the United Kingdom decreased relative to the incidence in other G10 countries), the estimator of difference-in-differences should be less than one (since the results are presented in terms of incidence-rate ratios) and statistically significant. In all the estimations, the time cutoff to distinguish the post-reform and the pre-reform observations is the first quarter of 2011 because, as described in more detail in Section 2.4, the Code Committee of the Takeover Panel published the consultation paper that formally proposed the amendments to the Takeover Code (PCP 2011/1) in that quarter. The results, however, are qualitatively similar if we set the cutoff at the fourth quarter of 2010 (when the Takeover Panel first proposed the elimination of deal protection devices), the second quarter of 2011 (when the Takeover Panel formally adopted the reforms) or the fourth quarter of 2011 (when the reforms entered into force).

We also control for other mean characteristics of the targets, the acquirers and the deals at the quarter-country level. These characteristics include the mean size of the deals announced in the respective quarter, percent of shares sought in the transactions, consideration structure (all-cash versus other forms of payment), public status of the acquirers (public versus private acquirer), type of acquirer (financial versus strategic), and the target's nation's gross domestic product (GDP) growth rate in the year of the observation. In sensitivities analyses, we also run the regressions using median values of deal size, lagged GDP growth rates for the target's country (instead of the contemporaneous measure), and the growth rate of the target's nation's main stock exchange equities index (instead of using GDP figures).

country level data, which allows us to use relatively similar economies as a control group for the count of quarterly deals and the other variations of the dependent variable discussed in the sensitivity analysis.

${ }^{14}$ When referring to hierarchical models, we use the standard definitions of random effects (factors that vary within each country) and fixed effects (factors that vary only between countries) even though those definitions are not equivalent to the definitions of random and fixed effects in other contexts of longitudinal analysis. 
In addition to analyzing the effect of the reform on deal incidence, as mentioned, we also examine its effect on competing bids, deal jumping, deal premiums, and completion rates. Given the nature of this part of the analysis, we use the transaction-level data instead of forming a quarterly panel.

For the analysis of competing bids, we employ a random effects logit model in which the dependent variable is a dummy for the presence of a competing bidder. For the analysis of deal jumping rates, we run a random effects logit model with the subset of challenged deals and use as the dependent variable a dummy set to one if a challenged deal was effectively jumped and zero otherwise.

For the analysis of premiums, we use a random effects regression model with the same controls discussed above and we run the model for three definitions of the dependent variable: premiums over the target's stock market price one day, one week, and four weeks prior to announcement. In order to mitigate the effect of outliers, we truncate the premium at $200 \%$ (but the results are qualitatively similar without truncation or if we winsorize at $1 \%)$.

Finally, for the analysis of deal completion rates, we use a random effects logit model in which the dependent variable is a dummy set to one if the deal was completed and zero otherwise.

The data for our sample comes from the Thomson Merger and Acquisitions database. We began with all the transactions announced during the period and for the countries mentioned above, and then applied the following filters. First, we excluded all the transactions that involved a bankruptcy, a liquidation proceeding, a repurchase of shares, a restructuring or a recapitalization. Second, we retained only the transactions that were listed as completed, unconditional (applicable to UK companies) or withdrawn. Third, we retained only transactions in which the buyer owned less than $35 \%$ of the shares of the target at announcement (in order to exclude parent/subsidiary transactions) and transactions in which the buyer sought or effectively acquired at least $20 \%$ of the shares of the target (which eliminates from the sample small stock purchases). Finally, we excluded transactions for which there was no information about the value of the transaction. The final dataset includes 3,953 observations. This final dataset was then merged with databases containing information on each country's GDP growth rate and the target's nation's main stock exchange equities index. The information on GDP growth rates comes from the International Monetary Fund and the information on stock exchange indices comes from Datastream. As mentioned before, using this data, we constructed a panel using mean and median values at the quarter-country level in order to perform the analysis of deal volume. The panel contains 478 observations at the quartercountry level. 


\section{Results}

\subsection{Summary statistics}

Panel A of Table 2 shows summary statistics for all the quarterly observations, breaking down the sample by group (the United Kingdom versus the control group of European G10 economies) and period (before and after the reform). The results in the table provide preliminary evidence that, in fact, the incidence of deals in the United Kingdom decreased after the 2011 Reform relative to other G-10 economies. Before the reform, approximately $50 \%$ of all deals in the sample involved targets from the United Kingdom $(1,530 / 3,052)$. After the reform, this proportion fell to approximately $34 \%(310 / 901)$. This difference between the pre and post reform periods was significant at $1 \%$ (the $z$ statistic from a difference in proportion test using all the transactions in the sample was 7.68).

Similarly, before the reform, the mean number of deals by quarter in the United Kingdom was 34.77 and the mean number of deals by quarter in each of the other G-10 economies was 5.27. This implies that the mean number of deals by quarter in the United Kingdom was approximately 6.6 times the mean number of deals by quarter in the countries that form the control group. After the reform, the mean number of deals by quarter in the United Kingdom fell to 15.4, while the mean number of deals in other European G-10 jurisdictions remained relatively similar ( 4.73 by quarter). As a result, the ratio of the mean number of deals in the United Kingdom to the mean number of deals in the control group fell to 3.25 (that is, the post-reform ratio of quarterly UK deals to the mean number of quarterly deals in the control group was approximately $50 \%$ the same ratio during the pre-reform period).

Following Coates (2010), we also normalized the data by taking the ratio of the number of deals to the number of listed firms in each country and quarter. After this adjustment, the results again suggest that the incidence of U.K. deals declined after 2011 relative to the control group. Specifically, before the reform, the proportion of deals to listed firms by quarter was $1.42 \%$ in the United Kingdom and $1.37 \%$ in the control group, and the difference was not statistically significant under a $t$-test. After the reform, the proportion was $0.82 \%$ in the U.K. and $1.47 \%$ in the control group, and the difference became statistically significant at $1 \%$. These figures imply that the ratio of deals to listed companies in the U.K. to the ratio of deals to listed companies outside the U.K. after the reform was approximately $53.8 \%$ times the same ratio prior to the reform (computed as: $((0.82 / 1.47) /(1.42 / 1.37)) \times 100)$.

Figure 1, Panel A illustrates the effect of the reform using the total number of deals in the United Kingdom and in the control group, and then smoothing the data by a moving average over four periods. As shown in the figure, the total number of transactions in the United Kingdom and in the control group followed similar trajectories before the reform, but a significant gap emerged between these trajectories after (approximately) the first quarter of 2011. This pattern is similar when taking the ratio of deals to listed firms instead of the raw number of deals (Panel B). 
In contrast to these results, Panel $\mathrm{B}$ of Table 2 also shows that there are no significant differences in the U.K. in the incidence of competing bids, deal jumping, deal premiums, and completion rates after the 2011 Reform. Univariate tests ( $t$-test in the case of premiums and difference in proportion tests for the remaining variables) confirm this.

\subsection{Regression analysis}

Table 3 presents the regression results. Model 1 presents the results of the random effects Poisson regression model with only the $U K$, the Post-Reform, and the $U K \times$ Post-Reform variables; Model 2 presents the results of the same model using all the control variables; Model 3 presents the results of the random effects negative binomial regression; and Model 4 presents the results of the hierarchical model that allows for a random intercept at the country level. All the results are presented in terms of incidence-rate ratios.

Similar to the univariate analysis discussed before, the regression results are consistent with the hypothesis that the reform to the Takeover Code had a negative effect on deal volumes in the U.K. In all the specifications, the estimator of difference-in-differences was less than one and statistically significant at $1 \%$. In terms of the magnitude of the effect, the point estimate (approximately 0.5 in all the models) indicates that the incidence-rate ratio of U.K. deals to non-U.K. deals after the reform was approximately $50 \%$ the incidence-rate ratio of U.K. deals to non-U.K. deals prior to the reform. In other words, the interaction term $U K \times$ Post-Reform in the Poisson model is the ratio of two incidence-rate ratios: (i) the post-reform incidence-rate of U.K. deals to the average incidence-rate of deals in the countries of the control group, and (ii) the pre-reform incidence-rate of U.K. deals to the average incidence-rate of deals in the countries of the control group.

In Panel A of Table 4 we present the results of alternative specifications. In Model 1 we replaced the mean values of deal size in each quarter with median values; Model 2 replaces the GDP growth rate of the target's nation with the GDP growth rate lagged by one year; and Model 3 replaces the GDP growth rate variable with the growth rate of the target's nation's stock exchange equities index. Finally, in Model 4 we adjusted for autocorrelation. To do this, we ran a generalized estimating equation (GEE) with an autoregressive correlation structure of order one (AR(1)). As shown in the table, the statistical significance and magnitude of the difference-in-differences estimator was consistent across all the specifications.

Panel B of Table 4 shows additional sensitivity analyses from alternative samples. In Model 1, we use a shorter time frame (2005-2015) to mitigate the potential effect of confounding events. This model yields a difference-in-differences estimator that is very similar to the baseline regression in terms of magnitude $(0.49)$ and statistical significance (the variable is significant at 1\%). In unreported estimations, we used a still shorter time window of approximately 3 years around the reform (2008-2013) and the results remained qualitatively similar (although the magnitude of the effect actually became larger, yielding a difference-in-differences estimator of approximately 0.4 ). 
In Model 2, we use the quarterly ratio of deals to listed companies ((deals/listed companies $) \times 100$ ) as the dependent variable instead of using the raw number of deals. In addition, we use a random effects GLS model instead of the random effects Poisson model due to the nature of the dependent variable (continuous as opposed to discrete). As shown in the table, the difference-in-differences estimator is negative $(-0.71)$ and statistically significant at $1 \%$. This point estimate indicates that, after the reform, the average proportion of deals to listed firms in the United Kingdom declined relative to the control group in approximately 0.7 percent points. This similar to the univariate results in Table $2((0.82-1.47)-(1.42-1.37)=-0.7)$. Because the test proposed by D'Agostino, Belanger, and D'Agostino (1990) showed that the ratio of deals to listed companies was skewed (the null hypothesis of no skewedness was rejected at $1 \%$ ), we also ran the regressions using a logarithmic transformation of the dependent variable. When we did this, the difference-in-differences was again negative and statistically significant at $1 \%$. The point estimate of the coefficient was -0.63 , which indicates that the ratio of deals to listed companies in the U.K. decreased by approximately $46.74 \%$ after the 2011 Reform relative to the control group [computed as: $\exp (-0.63)-1) \times 100]$. In other words, the ratio of deals to listed companies in the U.K. to the ratio of deals to listed companies outside the U.K. after the reform was approximately $53.26 \%$ times the same ratio prior to the reform (calculated as $\exp (-0.63)$ ). This is result is also very similar to the univariate estimations discussed in Part 4.1 (as shown there, $((0.82 / 1.47) /(1.42 / 1.37)) \times 100)=$ $53.8 \%)$.

In Model 3 we return to the baseline dependent variable (number of deals by quarter) but use the U.S. as the control group instead of the control group of European G-10 economies (and, therefore, we use a regular Poisson model instead of the random effects Poisson model). The point estimate of the difference-in-differences estimator in this specification is again less than one and statistically significant at $1 \%$, meaning that the incidence of U.K. deals declined after the 2011 Reform not only relative to other European G-10 economies, but also relative to the U.S. The point estimate is approximately 0.8 , which indicates that the incidence-rate ratio of U.K. deals to U.S. deals after the reform was approximately $80 \%$ the pre-reform ratio. In this sense, the drop in the incidence of U.K. deals relative to U.S. deals was smaller than the drop in the incidence of U.K. deals relative to other European G-10 countries, but as mentioned, the decline was statistically significant at $1 \%$ in both cases.

Finally, to mitigate the effect of small deals in the sample, in Model 4 we only use transactions over $\$ 50$ million to construct the quarterly panel and run the baseline random effects Poisson model with this dataset. As shown in the table, the results are again qualitatively similar (the magnitude of the difference-in-differences estimator is approximately 0.5 and the variable is statistically significant at $1 \%$ ).

In unreported estimations, we ran all the Poisson models in the sensitivity analyses using the random effects negative binomial and the hierarchical specifications discussed in Table 2 (we only ran the hierarchical specification when using the control group of European G-10 economies due to the nature of the data). We also extended the baseline specifications by running hierarchical models that allowed sequentially for random slopes 
for each of the variables that vary within country. In addition, we ran all the models including simultaneously the contemporaneous and the lagged GDP growth rates, and including the growth rate for the target's nation's stock exchange equities index and the GDP growth rate. Finally, we also ran the regressions with a panel constructed only with friendly deals (where deal protection is most relevant) and with models that included additional controls to account for pre-deal performance of the targets and market conditions. These additional controls included pre-deal return on assets (ROA), the ratio of capital expenditures to assets (CAPEX), sales growth over the last year (or last two years) prior to announcement, and the level of capital liquidity for each country (defined as in Harford (2005) and Cain, McKeon, and Davidoff (2016), that is, as the spread between the rate of commercial and industrial loans minus the relevant interbank rate). Because the financial variables that account for the targets' pre-deal performance had missing values even after forming the quarter-country level panel, we ran the regressions without those observations and also using mean imputation. In all these specifications, the results remained qualitatively similar. ${ }^{15}$

In terms of the dollar amount of lost deal volume, in unreported estimations we also ran a random effects regression model in which the dependent variable was the total value (in millions of dollars) of all the deals announced in the respective country and quarter, and the dependent variables included only the UK, Post-Reform, and UK $\times$ Post-Reform variables. To avoid the influence of outliers, we winsorized the dependent variable at $1 \%$. In this regression model, the difference-in-differences estimator was negative and statistically significant at $1 \%$. The coefficient was approximately $-19,000$, indicating that the total deal volume per quarter in the U.K. decreased in approximately USD 19 billion relative to the control group after the 2011 Reform. When the other controls shown in Models 2 through 4 of Table 3 are included in the regression, the difference-indifferences estimator is still significant at $1 \%$ and the point estimate increases to approximately $-19,325$, implying a quarterly loss of approximately USD 19.3 in deal volume for the U.K. Assuming an average premium of $20 \%$ over stock market prices prior to announcement (which, as shown in Table 2, is a conservative estimate for the U.K.), the previous computations imply a quarterly loss of approximately USD 3.2 billion for U.K. target shareholders (calculated as: USD19.3 billion - USD19.3/1.2). ${ }^{16}$

We also estimated the dollar amount of lost deal volume in three alternative ways (for all these estimations, we used the baseline regression model in Model 2 of Table 3). First, to

\footnotetext{
${ }^{15}$ Another approach to estimating the effect of the 2011 Reform would be to pool the data from the European G-10 economies and using that aggregated set as the control group. If we run the quarterly data using this approach, the estimator of difference-in-differences estimator in the random effects Poisson regression model is similar $(0.52)$ and the variable is significant at $1 \%$ (in both the simple and the multivariate models). In addition, the U.K. variable (which measures the pre-reform difference between the incidence of U.K. deals and the incidence of deals in the pooled control group) was 1.0005 and was not significant (indicating that, before the reform, there was no significant difference between the U.K. and the control group in terms of deal volume). This is not our preferred approach, however, since it does not take into account within-country factors and also reduces significantly the number of observations for the analysis (from 478 to 128 ).

${ }^{16}$ We obtain qualitatively similar estimations if we use the panel formed only of deals over USD 50 million, although in that case the estimated loss of deal volume per quarter is approximately USD 17.3 million.
} 
further mitigate the influence of outliers, we winsorized the quarterly deal value at $5 \%$. In this case, the difference-in-differences estimator was $-17,882.32$ and the variable was significant at $1 \%$, implying a quarterly lost value of approximately USD 17.9 billion relative to the control group.

Second, we ran Huber-White robust and median regressions. Using these approaches, we obtained a difference-in-differences estimator of $-18,086.62$ and $-15,425.15$, respectively. In both cases again, the variable was significant at $1 \%$. These estimations imply a quarterly loss of deal value of approximately USD 18 billion or USD 15.4 billion, respectively. In the case of the lower figure, this would imply a quarterly loss for the U.K. shareholders of USD 2.5 billion (assuming a 20\% premium).

Third, we ran the skewedness test described in D'Agostino, Belanger, and D'Agostino (1990) and rejected (at 1\%) the null hypothesis that the quarterly dollar value of deal volume is not skewed. Therefore, we ran again the regression model using a logarithmic transformation of that variable. Using this approach, the difference-in-differences estimator was -0.66 and was statistically significant at $1 \%$, implying a lost deal volume of $48.3 \% .^{17}$

In addition to these approaches, we also ran the baseline regression model for the ratio of the quarterly dollar value of all deals to GDP (that is, (deal value / GDP) $\times 100$ ). Using this approach, the difference-in-differences estimator was negative and statistically significant at $1 \%$. This was true with and without winsorization (either at $1 \%$ or $5 \%$ ), and also for Huber-White and median regressions. The point estimate of the difference-indifferences estimator in the baseline regression was -0.0097 , which implies a postReform decrease of 0.0097 percent points in the quarterly ratio of deal volume to GDP in the U.K. relative to the control group. Because, similar to the raw value of deal volume, we rejected the null hypothesis that the ratio of deal value to GDP was not skewed under the test proposed by D'Agostino, Belanger, and D'Agostino (1990), we also ran the regressions using a logarithmic transformation of the dependent variable. In this case again, the difference-in-differences estimator was negative and statistically significant at

\footnotetext{
${ }^{17}$ Similar to the baseline Poisson models, we also ran the regressions for the dollar amount of deal volume after pooling the European G-10 countries of the control group as a single group. In that case, the estimated quarterly loss of deal volume in the U.K. was approximately USD 8.7 billion per quarter relative to the control group, but the difference-in-differences estimator was not significant. At least in part, this reduction in the statistical significance might be due to the drop in the number of observations (from 478 to 128) that results from pooling the data of the control group instead of using the more granular country-level information. However, when we use the logarithmic transformation of the dependent variable to correct for skewedness, the difference-in-differences estimator is again significant at 1\% (and the point estimate is 0.64 , implying a lost deal volume of $47.3 \%$ ). As discussed before, however, pooling all the information from the countries that constitute the control group is not our preferred specification due to the loss of information and degrees of freedom. On the other hand, as in the baseline analysis, we also ran the regressions for the dollar value of deal volume using the U.S. as the control group. In this case, the difference-in-differences estimator was not significant. However, when we use the logarithmic transformation of the dependent variable, the difference-in-differences estimator was negative (-0.29) and statistically significant at $1 \%$. Taking that coefficient, the estimated post-reform decline in the quarterly value of deal volumes in the U.K. was approximately $25 \%$ relative to the U.S.
} 
$1 \%$. The results were directionally similar when we ran the regressions using the U.S. as a control group. ${ }^{18}$

As mentioned in Part 3, in addition to analyzing the effect of the 2011 Reform on deal incidence, we also examined whether the reform had any effect on the incidence of competing bids, deal jumping rates, deal premiums, and completion rates. The results are presented in Table 5. Model 1 shows the results for the incidence of competing bids, Model 2 shows the results for jump rates in the subset of challenged deals, Model 3 shows the results for deal premiums (over market prices four weeks prior to announcement), and Model 4 shows the results for completion rates. As shown in the table, the difference-in-differences estimator is not significant in any specification, implying that the 2011 Reform does not seem to have affected any of these deal outcomes. Unreported regressions also show that the difference-in-differences estimator is not significant if we replace the random effects logit specification in Model 4 with a Cox model or with parametric duration models (exponential or Weibull), which take into account the time-to-completion component. In addition, the difference-in-differences estimator is also statistically indistinguishable from zero in Model 3 if we do not truncate the premiums at $200 \%$ (which we did in the reported results to avoid the influence of extreme values), if we winsorize the data at $1 \%$ or if we use premiums over market prices one day or one week prior to announcement.

\section{Discussion}

Taken as a whole, the results indicate that deal volumes declined after the U.K. prohibited deal protection devices in 2011. The decline in deal volumes that we report is statistically significant and economically meaningful. As mentioned before, we estimate that the post-reform incidence-rate ratio of U.K. deals to the average number of deals per quarter in the countries of the control group was approximately $50 \%$ the pre-reform ratio. In addition, we estimate USD 19.3 billion in lost deal volumes per quarter in the U.K. relative to the control group, which implies a quarterly loss of USD3.3 billion for shareholders of U.K. companies since the 2011 Reforms were put in place (if we assume a conservative premium of $20 \%) .{ }^{19}$

\footnotetext{
${ }^{18}$ Using, as before, the pooled version of the E.U. G-10 control group, the difference-in-differences is also negative and statistically significant (at $10 \%$ in the original version of the dependent variable and at $1 \%$ in the version that uses the logarithmic transformation).

${ }^{19}$ Because the 2011 Reforms prohibited lockups generally, we cannot identify conclusively which prohibition in particular was most relevant in causing the decline in deal volumes presented in this paper. This limitation is compounded by the fact that there is no systematic data on the full array of protections that the reform prohibited and even for the available data, the information from Thomson Financial is not entirely reliable. Boone and Mulherin (2007) and André, Khalil, and Magnan (2007), for example, find that, relative to a careful review of SEC filings, Thomson underreports the incidence of breakup fees and other forms of deal protections. Casual observation, in fact, suggests that some of the deal protections that are not reported by Thomson might have been quite frequent before the 2011 Reform. For example, when announcing the reforms, the Takeover Panel stated in PCP 2011/1 that "The Code Committee noted that it has now become standard market practice in the context of recommended offers for offerors to have the benefit of a number of deal protection measures." Similarly, the Takeover Panel mentioned in PCP 2010/1 several devices that, according to the Panel, appeared to be "typical" (Takeover Panel, 2010a). In addition to all these factors, other disclosure obligations introduced by the reform, like the mandatory "put up or
} 
On the other hand, we find no discernible countervailing benefits for target shareholders in the form of higher deal premiums in deals that were done, through greater ex post competition (either explicit or implicit) that might arise from the absence of deal protection.

For transactional practice, our results indicate that the ex ante benefits of deal protection are real: that is, potential bidders are deterred from initiating M\&A deals when they cannot recoup their out-of-pocket expenses and other costs in a failed M\&A deal. This finding in consistent with practitioner wisdom that initiating an M\&A deal requires a significant investment of managerial resources, including personal reputational capital. Empirical studies show, for example, that CEO turnover occurs often in failed acquisitions, particularly when the market reacts negatively to the announcement of the transaction (Lehn and Zhao, 2006). There is also strategic vulnerability if an announced deal is then taken away. These practical realities might explain some of the underlying qualitative dynamics for our empirical finding.

Our results cast doubt on the wisdom of academic proposals arguing for a prohibition on termination fees (e.g., Schwartz, 1986). They also cast doubt on the wisdom of the policy choice in most G-10 countries to strongly discourage or prohibit termination fees. By doing so, these countries implicitly favor ex post competition over ex ante deal initiation. Our findings suggest that ex ante deal initiation is "elastic" to the cost of that initiation; therefore, the costs associated with such initiation should be acknowledged and accommodated by policymakers.

Our findings do not provide insight on the socially optimal level of termination fees that is, the level that properly balances the ex ante benefits with the ex post costs of deal protection. Our results suggest that as little as a $1 \%$ termination fee can create a statistically significant and economically meaningful increase in deal volumes. However, we do not know whether deal volumes increase linearly with further increases in the magnitude of permissible termination fees, or even whether they are increasing in deal protection magnitude beyond the $1 \%$ level that we test. In our judgment, the U.S. approach of permitting $4-5 \%$ termination fees probably goes too far. In terms of ex ante benefits, $5 \%$ of deal value is well excess of out-of-pocket costs and likely overcompensates bidders even when opportunity costs and other factors are considered as well. In terms of ex post costs, theoretical models indicate that deal protections of 3\% can deter bids, and the empirical evidence is consistent with this theoretical prediction (see, e.g., Coates and Subramanian 2000). This leads us to the overall conclusion that, in our judgment, the U.K. does not go far enough, and the U.S. goes too far, in permitting deal protection.

shut up" rule (which, as discussed before, requires that potential bidders make explicit their intentions within 28 days from the date they are identified as bidders) might also have had a deterrent effect. We therefore leave open for future research the question of whether or not there was any prohibition of a deal protection in particular that was more relevant than others in causing the decline in deal volumes presented in this paper. 


\section{Conclusion}

The 2011 Reforms in the U.K. present a rare opportunity for a natural experiment on some of the core questions that underlie deal protection theory and policy. To our knowledge, this paper presents the first analysis of the effect of the 2011 Reforms. We find that M\&A deal volumes in the U.K. declined significantly in the aftermath of the 2011 Reforms, relative to deal volumes in other European G-10 countries. We find no countervailing benefits to target shareholders in the form of higher deal premiums or a higher incidence of competing offers. In addition, deal jumping and deal completion rates also remained similar after the reform. We estimate a decline of 50\% in the incidencerate ratio of U.K. deals to the average number of deals per quarter in the countries that form the baseline control group. In addition, we estimate USD 19.3 billion in quarterly lost deal volumes, implying a loss of USD3.3 billion per quarter for shareholders of U.K. companies. Our results suggest that deal protections provide an important social welfare benefit by facilitating the initiation of M\&A deals. 


\section{Table 1 \\ Summary of deal protection regimes in the U.K., the control group of European G- 10 economies, and the U.S.}

The table summarizes the deal protection regimes in the U.K., each of the countries that constitute the baseline control group of European G-10 economies (Belgium, France, Germany, Italy, the Netherlands, Sweden, and Switzerland), and the U.S. Information on the law on the books and the law as applied comes from the Thomson Financial M\&A Database, statutory documents, Practical Law Global Guide 2015/2016 - Public Mergers and Acquisitions (Item 10) and 2010/2011.

\begin{tabular}{|c|c|c|}
\hline Country & Law on the Books & Law as Applied \\
\hline Belgium & $\begin{array}{l}\text { Break fees must be in the target's best } \\
\text { interests }\end{array}$ & Deal protection not used \\
\hline France & $\begin{array}{l}\text { Break fees can be challenged as an } \\
\text { unlawful deterrent if they are } \\
\text { excessive in amount. }\end{array}$ & Used in $<<1 \%$ of deals \\
\hline Germany & $\begin{array}{l}\text { Break fee must be in the target's best } \\
\text { interests }\end{array}$ & Not used \\
\hline Italy & $\begin{array}{l}\text { Break fee must be in the target's best } \\
\text { interests }\end{array}$ & Used in $<<1 \%$ of deals \\
\hline Netherlands & $\begin{array}{l}\text { Breakup fees are permitted, but } \\
\text { directors can be liable for } \\
\text { mismanagement if the fee is } \\
\text { disproportionately high. }\end{array}$ & Used in approximately $10 \%$ of deals \\
\hline Sweden & $\begin{array}{l}\text { Break fees must be in the target's best } \\
\text { interest, and the target must ensure } \\
\text { that there are special reasons to justify } \\
\text { the fee }\end{array}$ & $\begin{array}{l}\text { Used in }<<1 \% \text { of deals, and typically capped } \\
\text { at the bidder's out-of-pocket costs }\end{array}$ \\
\hline Switzerland & $\begin{array}{l}\text { Break fees are valid if structured as } \\
\text { compensation for costs incurred }\end{array}$ & $\begin{array}{l}\text { Used in }<<1 \% \text { of deals, but typically capped at } \\
\text { the bidder's out-of-pocket costs }\end{array}$ \\
\hline $\begin{array}{l}\text { United } \\
\text { Kingdom }\end{array}$ & $\begin{array}{l}\text { Breakup fees not permitted after the } \\
2011 \text { Reform }\end{array}$ & $\begin{array}{l}\text { Deal protection not used after the } 2011 \\
\text { Reform. }\end{array}$ \\
\hline United States & Breakup fees permitted & $\begin{array}{l}\text { Used in almost all deals and typically do not } \\
\text { exceed } 4 \% \text { of deal value. }\end{array}$ \\
\hline
\end{tabular}




\section{Table 2 \\ Descriptive statistics}

The table presents summary statistics for the quarterly data before and after the 2011 reform to the U.K. Takeover Code (Panels A and B) and transaction-level descriptive statistics for additional deal outcomes (Panels $\mathrm{C}$ and $\mathrm{D}$ ). The quarterly figures for the control variables were constructed using mean values from the transaction-level dataset (in sensitivity analyses of the regression estimates, however, we also use median values for deal size). The statistics for the non-U.K. economies are pooled statistics for the control group of European G-10 economies, which include: Belgium, France, Germany, Italy, Netherlands, Sweden, and Switzerland. Deals is the actual number of deals by quarter. Deal value is the quarterly (mean) value in USD millions of the transactions involving targets from the respective country. Shares sought and Shares held are the percentage of shares sought in the transaction and the percentage of shares held by the acquirer at announcement, respectively. GDP growth rate is the target's country's growth rate of the GDP. Completed, All-cash, Public acquirer, and Financial acquirer are the proportion of deals by quarter that were completed, that involved an all-cash consideration structure, that involved a publicly traded acquirer, and that involved a financial acquirer, respectively. Listed companies is the average number of listed companies in the corresponding period. Deals to listed companies is the average ratio of deals to listed companies per quarter, that is, (deals / listed companies) $\times 100$. Premium 1 day, Premium 1 week, and Premium 4 week are the premiums over deal prices 1 day, 1 week, and 4 weeks prior to announcement. Completed is a dummy variable set to one if the deal was completed and zero otherwise. Challenged is a dummy set to one if there was a competing bid and zero otherwise. Deal jumped is a dummy set to one if the target was bought by a competing bidder and zero otherwise. Summary statistics for deal jumping are computed using only the subset of challenged deals. The number of pre and postReform observations for the treatment and the control groups are slightly different in the quarter-level and transaction-level tables because the first quarter of 2011 (which marks the cutoff for the pre/post reform variable at the quarter-level data) includes some deals that are actually not "post-Refom" in the transactionlevel analysis (deals before March 21, 2011).

Panel A. Descriptive statistics for the quarterly data

Panel A.1. Pre-reform descriptive statistics for the quarterly data

\begin{tabular}{|c|c|c|c|c|c|c|}
\hline \multirow{2}{*}{ Variable } & \multicolumn{3}{|c|}{ UK transactions } & \multicolumn{3}{|c|}{ Transactions in non-UK countries } \\
\hline & Mean & Median & Std. Dev. & Mean & Median & Std. Dev. \\
\hline Deals & 34.77 & 34.00 & 9.88 & 5.27 & 5.00 & 3.59 \\
\hline Deal value & 967.03 & 706.45 & 955.13 & 862.73 & 318.90 & 2635.95 \\
\hline Shares sought & 78.51 & 80.19 & 9.70 & 61.21 & 61.24 & 24.35 \\
\hline Shares held & 3.35 & 3.41 & 1.72 & 3.53 & 1.76 & 4.92 \\
\hline GDP growth rate & 1.82 & 2.59 & 2.20 & 1.54 & 1.95 & 2.33 \\
\hline Completed (\%) & 87.65 & & & 91.84 & & \\
\hline All-cash (\%) & 50.25 & & & 48.21 & & \\
\hline Public acquirer (\%) & 43.76 & & & 41.26 & & \\
\hline Financial acquirer (\%) & 21.33 & & & 22.64 & & \\
\hline Listed companies & 2456.82 & 2428 & 224.98 & 410.04 & 284 & 237.20 \\
\hline Deals to listed companies & 1.42 & 1.37 & 0.38 & 1.37 & 1.19 & 0.81 \\
\hline $\begin{array}{l}\text { Number of country-c } \\
\text { observations }\end{array}$ & & 44 & & & 289 & \\
\hline Total sum of deals & & 1530 & & & 1522 & \\
\hline
\end{tabular}


Panel A.2. Post-reform descriptive statistics for the quarterly data

\begin{tabular}{|c|c|c|c|c|c|c|}
\hline \multirow{2}{*}{ Variable } & \multicolumn{3}{|c|}{ UK transactions } & \multicolumn{3}{|c|}{ Transactions in non-UK countries } \\
\hline & Mean & Median & Std. Dev. & Mean & Median & Std. Dev. \\
\hline Deals & 15.40 & 15.00 & 4.92 & 4.73 & 4.00 & 3.82 \\
\hline Deal value & 1246.94 & 480.66 & 2335.55 & 1509.01 & 206.76 & 4979.56 \\
\hline Shares sought & 80.85 & 79.44 & 8.96 & 55.86 & 54.30 & 24.73 \\
\hline Shares held & 3.25 & 2.89 & 2.44 & 4.57 & 1.95 & 6.78 \\
\hline GDP growth rate & 2.08 & 2.16 & 0.55 & 0.92 & 1.01 & 1.41 \\
\hline Completed (\%) & 88.74 & & & 92.39 & & \\
\hline All-cash (\%) & 66.30 & & & 53.30 & & \\
\hline Public acquirer $(\%)$ & 39.39 & & & 34.22 & & \\
\hline Financial acquirer $(\%)$ & 18.35 & & & 19.52 & & \\
\hline Listed companies & 1887.80 & 1858 & 51.59 & 334.46 & 278 & 181.38 \\
\hline Deals to listed companies & 0.82 & 0.81 & 0.24 & 1.47 & 1.22 & 0.91 \\
\hline $\begin{array}{l}\text { Number of country-quarter } \\
\text { observations }\end{array}$ & & 20 & & & 125 & \\
\hline Total sum of deals & & 310 & & & 591 & \\
\hline
\end{tabular}

Panel B. Descriptive statistics for other deal outcomes (transaction-level data)

Panel B.1. Pre-reform descriptive statistics for other deal outcomes (transaction-level data)

\begin{tabular}{lcccccccc}
\hline \multirow{2}{*}{ Variable } & \multicolumn{4}{c}{ UK transactions } & \multicolumn{4}{c}{ Transactions in non-UK countries } \\
\cline { 2 - 9 } & Mean & Median & Std. Dev. & N & Mean & Median & Std. Dev. & Mean \\
\hline Premium 1 day & 28.05 & 20.65 & 51.64 & 1244 & 18.39 & 12.98 & 53.01 & 1033 \\
Premium 1 week & 33.47 & 25.60 & 69.26 & 1247 & 21.55 & 15.99 & 62.91 & 1032 \\
Premium 4 week & 35.51 & 27.94 & 64.61 & 1241 & 23.88 & 18.25 & 60.87 & 1028 \\
Completed (\%) & 87.23 & & & 1543 & 92.40 & & & 1540 \\
Challenged (\%) & 9.85 & & & 1543 & 6.10 & & & 1540 \\
Jumped (\%) & 27.63 & & & 152 & 25.53 & & & 94 \\
\end{tabular}

Panel B.2. Post-reform descriptive statistics for other deal outcomes (transaction-level data)

\begin{tabular}{lcccccccc}
\hline \multirow{2}{*}{ Variable } & \multicolumn{3}{c}{ UK transactions } & \multicolumn{4}{c}{ Transactions in non-UK countries } \\
\cline { 2 - 8 } & Mean & Median & Std. Dev. & N & Mean & Median & Std. Dev. & Mean \\
\hline Premium 1 day & 55.01 & 27.94 & 380.68 & 233 & 17.32 & 11.96 & 39.30 & 448 \\
Premium 1 week & 117.52 & 30.86 & 1288.80 & 230 & 18.15 & 12.78 & 40.38 & 445 \\
Premium 4 week & 47.71 & 30.72 & 237.13 & 233 & 22.14 & 16.67 & 42.42 & 446 \\
Completed (\%) & 89.56 & & & 297 & 93.02 & & 573 & 573 \\
Challenged (\%) & 9.43 & & & 297 & 4.89 & & & 28 \\
Deals jumped (\%) & 21.43 & & & 56 & 25.00 & & & \\
\hline
\end{tabular}




\section{Figure 1 \\ Number of deals and ratio of deals to listed companies over time}

The figure shows the evolution over time of the total number of deals in the U.K. and in all the countries that form the control group of European G-10 economies (Panel A) and the ratio of the number of deals to the number of listed companies in the same groups. The sample period is January 2000 to December 2015. The reference line is set at the first quarter of 2011, when the reform to the U.K. Takeover Code was formally announced. The data are quarterly and smoothed by a moving average over four periods.

Panel A. Number of deals over time in the U.K. and the control group of European G-10 economies

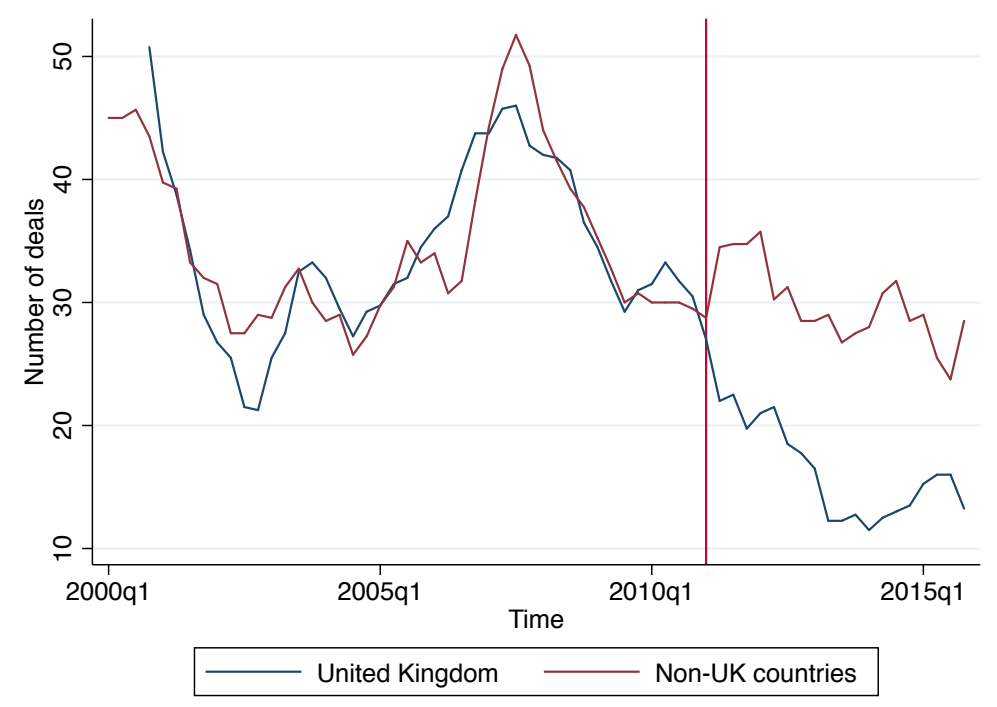

Panel B. Ratio of deals to listed companies in the U.K. and the control group of European G-10 economies

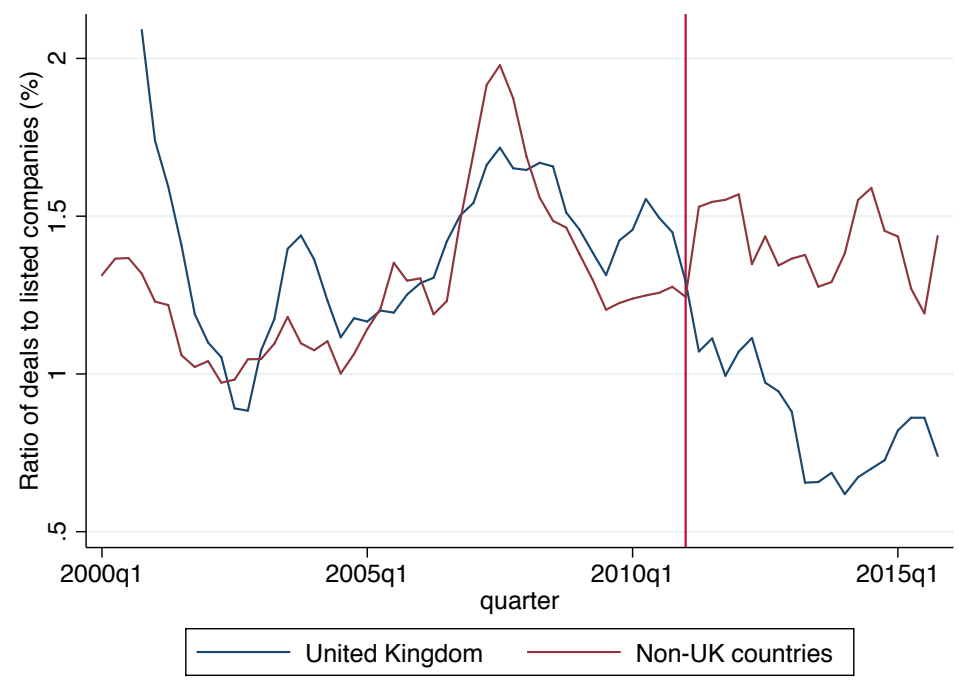




\section{Table 3 \\ Baseline regression results}

The table reports regression estimates on the association between the quarterly number of deals in the sample countries and the mean characteristics of the deals and the parties by quarter-country. Models 1 and 2 are random effects Poisson regression models. Model 3 is a random effects negative binomial regression model. Model 4 is a hierarchical model that allows for a random intercept by country. The dataset is based on all mergers and acquisitions involving U.K. targets and targets from other European G-10 countries between January 1, 2000 and December 31, 2015. All the coefficients are in exponentiated form (representing incidence-rate ratios) and the dependent variable in all the models is the quarterly count of deals. $*$ significant at $90 \%$ confidence; $* *$ significant at $95 \%$ confidence; $* * *$ significant at $99 \%$ confidence.

\begin{tabular}{|c|c|c|c|c|}
\hline Variable & Model 1 & Model 2 & Model 3 & Model 4 \\
\hline UK & $\begin{array}{c}6.793 * * * \\
(3.39)\end{array}$ & $\begin{array}{c}6.759 * * * \\
(3.33)\end{array}$ & $\begin{array}{c}2.785^{* *} \\
(1.22)\end{array}$ & $\begin{array}{c}7.647 * * * \\
(3.91)\end{array}$ \\
\hline Post-Reform & $\begin{array}{c}0.870 * * * \\
(0.04)\end{array}$ & $\begin{array}{c}0.907 * * \\
(0.05)\end{array}$ & $\begin{array}{c}0.889^{* *} \\
(0.05)\end{array}$ & $\begin{array}{c}0.907 * * \\
(0.05)\end{array}$ \\
\hline UK $\times$ Post-Reform & $\begin{array}{c}0.509 * * * \\
(0.04)\end{array}$ & $\begin{array}{c}0.498 * * * \\
(0.04)\end{array}$ & $\begin{array}{c}0.508 * * * \\
(0.05)\end{array}$ & $\begin{array}{c}0.498 * * * \\
(0.04)\end{array}$ \\
\hline $\log ($ deal value $)$ (mean) & & $\begin{array}{c}1.093 * * * \\
(0.01)\end{array}$ & $\begin{array}{c}1.094 * * * \\
(0.02)\end{array}$ & $\begin{array}{c}1.094 * * * \\
(0.01)\end{array}$ \\
\hline$\%$ Shares sought & & $\begin{array}{c}0.996 * * * \\
(0.00)\end{array}$ & $\begin{array}{c}0.996 * * * \\
(0.00)\end{array}$ & $\begin{array}{c}0.996^{* * * *} \\
(0.00)\end{array}$ \\
\hline All-cash & & $\begin{array}{l}0.986 \\
(0.07)\end{array}$ & $\begin{array}{l}0.988 \\
(0.08)\end{array}$ & $\begin{array}{l}0.986 \\
(0.07)\end{array}$ \\
\hline Public acquirer & & $\begin{array}{l}1.078 \\
(0.09)\end{array}$ & $\begin{array}{l}1.071 \\
(0.10)\end{array}$ & $\begin{array}{l}1.078 \\
(0.09)\end{array}$ \\
\hline Financial acquirer & & $\begin{array}{c}1.206^{* *} \\
(0.11)\end{array}$ & $\begin{array}{l}1.184 \\
(0.13)\end{array}$ & $\begin{array}{c}1.207 * * \\
(0.11)\end{array}$ \\
\hline Target's country's GDP growth rate & & $\begin{array}{c}1.029^{* * *} \\
(0.01)\end{array}$ & $\begin{array}{c}1.029 * * * \\
(0.01)\end{array}$ & $\begin{array}{c}1.029 * * * \\
(0.01)\end{array}$ \\
\hline Log-likelihood & -1204.356 & -1165.423 & -1148.416 & -1165.475 \\
\hline Wald chi-square & 191.607 & 268.040 & 160.354 & 268.936 \\
\hline Prob $>$ chi 2 & 0.000 & 0.000 & 0.000 & 0.000 \\
\hline Observations & 478 & 478 & 478 & 478 \\
\hline
\end{tabular}




\section{Table 4 \\ Sensitivity analysis}

Panel A. Alternative specifications

The table reports sensitivity analyses for the association between the quarterly number of deals in the sample countries and the mean characteristics of the deals and the parties each quarter. Models 1-3 are based on random effects Poisson regression estimations. Model 1 uses the natural logarithm of the median of deal value by country-quarter instead of using the mean. Model 2 uses the lagged GDP growth rate of the target's country instead of using the contemporaneous measure. Model 3 controls for the growth rate of the stock exchange equities index of the target's nation instead of controlling for GDP growth rate. Model 4 is a generalized estimating equation (GEE) model with an AR(1) correlation structure. All the coefficients are in exponentiated form (representing incidence-rate ratios) and the dependent variable in all the models is the quarterly count of deals. $*$ significant at $90 \%$ confidence; $* *$ significant at $95 \%$ confidence; $* * *$ significant at $99 \%$ confidence.

\begin{tabular}{|c|c|c|c|c|}
\hline Variable & Model 1 & Model 2 & Model 3 & Model 4 \\
\hline UK & $\begin{array}{l}7.363 * * * \\
(3.78)\end{array}$ & $\begin{array}{l}6.764 * * * \\
(3.34)\end{array}$ & $\begin{array}{l}6.799 * * * \\
(3.33)\end{array}$ & $\begin{array}{l}6.501 * * * \\
(0.39)\end{array}$ \\
\hline Post-reform & $\begin{array}{l}0.899 * * \\
(0.04)\end{array}$ & $\begin{array}{l}0.908^{*} \\
(0.05)\end{array}$ & $\begin{array}{l}0.880^{* *} \\
(0.04)\end{array}$ & $\begin{array}{l}0.902 \\
(0.07)\end{array}$ \\
\hline UK $\times$ Post-Reform & $\begin{array}{l}0.490 * * * \\
(0.04)\end{array}$ & $\begin{array}{l}0.499 * * * \\
(0.04)\end{array}$ & $\begin{array}{l}0.512 * * * \\
(0.04)\end{array}$ & $\begin{array}{l}0.490 * * * \\
(0.06)\end{array}$ \\
\hline Log (deal value) & & $\begin{array}{l}1.088 * * * \\
(0.01)\end{array}$ & $\begin{array}{l}1.094 * * * \\
(0.01)\end{array}$ & $\begin{array}{l}1.082 * * * \\
(0.01)\end{array}$ \\
\hline $\begin{array}{l}\text { Log (deal value) (median country- } \\
\text { quarter) }\end{array}$ & $\begin{array}{l}1.057 * * * \\
(0.02)\end{array}$ & & & \\
\hline$\%$ Shares sought & $\begin{array}{l}0.997 * * * \\
(0.00)\end{array}$ & $\begin{array}{l}0.996 * * * \\
(0.00)\end{array}$ & $\begin{array}{l}0.997 * * * \\
(0.00)\end{array}$ & $\begin{array}{l}0.997 * * * \\
(0.00)\end{array}$ \\
\hline All-cash & $\begin{array}{l}1.001 \\
(0.07)\end{array}$ & $\begin{array}{l}0.997 \\
(0.07)\end{array}$ & $\begin{array}{l}0.966 \\
(0.07)\end{array}$ & $\begin{array}{l}0.967 \\
(0.05)\end{array}$ \\
\hline Public acquirer & $\begin{array}{l}1.115 \\
(0.09)\end{array}$ & $\begin{array}{l}1.083 \\
(0.09)\end{array}$ & $\begin{array}{l}1.079 \\
(0.09)\end{array}$ & $\begin{array}{l}1.073 \\
(0.06)\end{array}$ \\
\hline Financial acquirer & $\begin{array}{l}1.173^{*} \\
(0.11)\end{array}$ & $\begin{array}{l}1.233^{* *} \\
(0.12)\end{array}$ & $\begin{array}{l}1.206^{* *} \\
(0.11)\end{array}$ & $\begin{array}{l}1.327 * * * \\
(0.09)\end{array}$ \\
\hline Target's country's GDP growth rate & $\begin{array}{l}1.033 * * * \\
(0.01)\end{array}$ & $\begin{array}{l}1.023 * * \\
(0.01)\end{array}$ & & $\begin{array}{l}1.027 * * \\
(0.01)\end{array}$ \\
\hline $\begin{array}{l}\text { Target's country GDP growth rate } \\
\text { (lagged) }\end{array}$ & & $\begin{array}{l}1.026^{* * * *} \\
(0.01)\end{array}$ & & \\
\hline $\begin{array}{l}\text { Target's stock exchange index growth } \\
\text { rate }\end{array}$ & & & $\begin{array}{l}1.337 * * * \\
(0.13)\end{array}$ & \\
\hline Log-likelihood & -1182.443 & -1164.028 & -1166.347 & \\
\hline Wald chi-square & 234.705 & 271.092 & 267.214 & 1279.032 \\
\hline Prob $>$ chi 2 & 0.000 & 0.000 & 0.000 & 0.000 \\
\hline Observations & 478 & 478 & 478 & 478 \\
\hline
\end{tabular}




\section{Panel B. Alternative samples}

The table reports additional sensitivity analyses using alternative samples. Model 1 shows the results of the baseline random effects Poisson model using a shorter time window (2005-2015). In Model 2, the dependent variable is the quarterly ratio of deals to listed companies in each country and the model was run using a GLS random effects model. Model 3 is a Poisson regression model in which the control group is the U.S. instead of the baseline control group of European G-10 economies. Model 4 is based on a panel comprised of only deals over $\$ 50$ million and the model was run using the baseline specification (random effects Poisson model). In Models 1, 3 and 4, the coefficients are in exponentiated form (representing incidence-rate ratios) and the dependent variable is the quarterly count of deals. $*$ significant at $90 \%$ confidence; $* *$ significant at $95 \%$ confidence; $* * *$ significant at $99 \%$ confidence.

\begin{tabular}{|c|c|c|c|c|}
\hline Variable & Model 1 & Model 2 & Model 3 & Model 4 \\
\hline UK & $\begin{array}{c}7.046^{* * *} \\
(3.44)\end{array}$ & $\begin{array}{l}0.026 \\
(0.13)\end{array}$ & $\begin{array}{c}0.282 * * * \\
(0.01)\end{array}$ & $\begin{array}{c}5.365^{* * *} \\
(1.90)\end{array}$ \\
\hline Post-Reform & $\begin{array}{c}0.869 * * \\
(0.05)\end{array}$ & $\begin{array}{l}0.146^{*} \\
(0.08)\end{array}$ & $\begin{array}{c}0.575^{* * * *} \\
(0.02)\end{array}$ & $\begin{array}{c}0.843 * * * \\
(0.06)\end{array}$ \\
\hline $\mathrm{UK} \times$ Post-Reform & $\begin{array}{c}0.487 * * * \\
(0.04)\end{array}$ & $\begin{array}{c}-0.710 * * * \\
(0.22)\end{array}$ & $\begin{array}{c}0.805^{* * *} \\
(0.06)\end{array}$ & $\begin{array}{l}0.542 * * * \\
(0.06)\end{array}$ \\
\hline $\log ($ deal value) (mean) & $\begin{array}{c}1.068 * * * \\
(0.02)\end{array}$ & $\begin{array}{c}0.113 * * * \\
(0.02)\end{array}$ & $\begin{array}{c}1.104 * * * \\
(0.02)\end{array}$ & $\begin{array}{c}1.142 * * * \\
(0.02)\end{array}$ \\
\hline$\%$ Shares sought & $\begin{array}{c}0.997 * * * \\
(0.00)\end{array}$ & $\begin{array}{c}-0.005^{* * *} \\
(0.00)\end{array}$ & $\begin{array}{c}0.986^{* * *} \\
(0.00)\end{array}$ & $\begin{array}{l}0.998^{*} \\
(0.00)\end{array}$ \\
\hline All-cash & $\begin{array}{l}0.998 \\
(0.10)\end{array}$ & $\begin{array}{l}-0.067 \\
(0.12)\end{array}$ & $\begin{array}{l}1.036 \\
(0.14)\end{array}$ & $\begin{array}{c}1.174 * * \\
(0.09)\end{array}$ \\
\hline Public acquirer & $\begin{array}{l}0.996 \\
(0.11)\end{array}$ & $\begin{array}{l}0.150 \\
(0.14)\end{array}$ & $\begin{array}{c}1.514 * * \\
(0.25)\end{array}$ & $\begin{array}{l}1.118 \\
(0.10)\end{array}$ \\
\hline Financial acquirer & $\begin{array}{l}1.162 \\
(0.13)\end{array}$ & $\begin{array}{c}0.406 * * * \\
(0.16)\end{array}$ & $\begin{array}{l}1.009 \\
(0.21)\end{array}$ & $\begin{array}{l}1.181^{*} \\
(0.12)\end{array}$ \\
\hline Target's country's GDP growth rate & $\begin{array}{c}1.032 * * * \\
(0.01)\end{array}$ & $\begin{array}{l}0.034 * \\
(0.02)\end{array}$ & $\begin{array}{c}1.045^{* * *} \\
(0.01)\end{array}$ & $\begin{array}{c}1.072 * * * \\
(0.01)\end{array}$ \\
\hline Log-likelihood & -787.040 & & -610.731 & -981.081 \\
\hline $\begin{array}{l}\text { Wald chi-squared } \\
\text { Likelihood ratio }\end{array}$ & 233.641 & 56.929 & 3831.781 & 222.848 \\
\hline $\begin{array}{l}\text { Prob }>\text { chi2 } \\
\text { R-squared (overall) }\end{array}$ & 0.000 & $\begin{array}{l}0.000 \\
0.108\end{array}$ & 0.000 & 0.000 \\
\hline $\begin{array}{l}\text { Pseudo R-squared } \\
\mathrm{N}\end{array}$ & 329 & 478 & $\begin{array}{c}0.758 \\
128\end{array}$ & 439 \\
\hline
\end{tabular}




\section{Table 5 \\ Incidence of competing bids, deal jumping, premiums, and deal completion}

The table reports regression estimates on the effect of the 2011 reform to the U.K. Takeover Code and various deal outcomes. In Model 1, the dependent variable is a dummy that takes the value of one if there was a competing bid and zero otherwise. This model and Models 2 and 4 were run using a random effects logit specification. In Model 2, the dependent variable is a dummy that takes the value of one if a competing bidder bought the target and zero otherwise. This specification only includes challenged deals. In Model 3, the dependent variable is the premium over the target's stock market price four weeks prior to announcement. This model was run using a GLS random effects specification. In Model 4, the dependent variable is a dummy variable that takes the value of one if the deal was completed and zero otherwise. In all the models, the control group consists of quarterly data for transactions involving targets from European G10 economies other than the U.K. The original sample has 3,953 observations, but Model 3 has fewer observations due to missing values in the premium data and in the data on the percentage of shares sought in the transaction (\% Shares sought). In the logit models, the number of observations is less than 3,953 also due to missing values in the \% Shares sought variable. When there were missing values for that variable, however, there was information on the number of shares effectively acquired. The results are similar if we replace the missing values for in the \% Shares sought variable with the percent of shares acquired in the transaction. The sample period is January 2000 - December 2015. All the coefficients in Models 1, 2, and 4 are in exponentiated form (representing odds ratios). * significant at $90 \%$ confidence; ** significant at $95 \%$ confidence; $* * *$ significant at $99 \%$ confidence.

\begin{tabular}{lcccc}
\hline & & & & \\
& Variable & Model 2 & Model 3 & Model 4 \\
\hline UK & 1.129 & 1.083 & $7.046^{* * *}$ & 0.795 \\
& $(0.17)$ & $(0.36)$ & $(1.64)$ & $(0.19)$ \\
Post-Reform & 0.930 & 1.142 & 3.261 & 0.972 \\
& $(0.22)$ & $(0.65)$ & $(2.14)$ & $(0.20)$ \\
UK $\times$ Post-Reform & 0.981 & 0.682 & -3.828 & 1.323 \\
& $(0.32)$ & $(0.52)$ & $(3.42)$ & $(0.39)$ \\
Log(deal value) & $1.355^{* * *}$ & 0.971 & $1.855^{* * *}$ & $0.799^{* * *}$ \\
& $(0.04)$ & $(0.08)$ & $(0.32)$ & $(0.02)$ \\
\% Shares sought & $1.031^{* * *}$ & 1.002 & $0.226^{* * *}$ & $0.977^{* * *}$ \\
& $(0.00)$ & $(0.01)$ & $(0.02)$ & $(0.00)$ \\
All-cash & $1.334^{* *}$ & 0.827 & $5.946^{* * *}$ & $0.715^{* * *}$ \\
& $(0.19)$ & $(0.25)$ & $(1.47)$ & $(0.09)$ \\
Public acquirer & 1.025 & 1.289 & 1.220 & $0.644^{* * *}$ \\
Financial acquirer & $(0.15)$ & $(0.43)$ & $(1.57)$ & $(0.08)$ \\
& 1.258 & 1.502 & $-5.247^{* * *}$ & 0.870 \\
Target's country's GDP growth rate & $(0.20)$ & $(0.53)$ & $(1.74)$ & $(0.13)$ \\
& 1.023 & 1.111 & 0.201 & $1.081^{* * *}$ \\
Log-likelihood & $(0.04)$ & $(0.10)$ & $(0.35)$ & $(0.03)$ \\
Wald chi-squared & & & & \\
Prob > chi2 & -893.896 & -168.184 & & -1094.704 \\
R-squared (overall) & 207.510 & 9.924 & 359.599 & 213.450 \\
N & 0.000 & 0.970 & 0.000 & 0.000 \\
& & & 0.11 & \\
& 3934 & 302 & 2920 & 3934 \\
\hline
\end{tabular}




\section{References}

André, P., S. Khalil, and M. Magnan. 2007. Termination fees in mergers and acquisitions: Protecting investors or managers? Journal of Business Finance and Accounting 34: 541- 66.

Bates, T.W., and M. L. Lemmon. 2003. Breaking up is hard to do? An analysis of termination fee provisions and merger outcomes. Journal of Financial Economics 69(3): 469-504.

Boone, A. L., and J. H. Mulherin. 2007. Do termination provisions truncate the takeover bidding process? Review of Financial Studies 20 (2): 461-89.

Burch, T.R. 2001. Locking out rival bidders: The use of lockup options in corporate mergers. Journal of Financial Economics 60(1): 103-41.

Cain, M., S. McKeon, and S. Davidoff Solomon. 2016. Do takeover laws matter? Evidence from five decades of hostile takeovers. Working paper.

Clifford Chance. European M\&A: On the road to recovery? Insights from the United States (May 2013). .

Coates, J. 2010. "M\&A break fees: U.S. litigation versus U.K. regulation," in Regulation vs. Litigation: Perspectives from Economics and Law, ed. D. Kessler (Chicago University Press, 2010) 239-284.

Coates, J., and G. Subramanian. 2000. A buy-side model of M\&A lockups: Theory and evidence. Stanford Law Review 53(2): 307-396.

D'Agostino, R. B., A. J. Belanger, and R. B. D'Agostino Jr. 1990. A suggestion for using powerful and informative tests of normality. American Statistician 44: 316-321.

Gelter, M. 2009. The dark side of shareholder influence: Managerial autonomy and stakeholder orientation in comparative corporate governance. Harvard International Law Journal 50: 129-134.

Hanson, J. and S. Fraidin. 1994. Toward unlocking lockups. Yale Law Journal 103(6): 1739-1834.

Harford, J. 2005. What drives merger waves? Journal of Financial Economics 77: 529560.

Lehn, K, and M. Zhao. 2006. CEO turnover after acquisitions: are bad bidders fired? Journal of Finance 61: 1759-1811. 
Officer, M.S. 2003. Termination fees in mergers and acquisitions. Journal of Financial Economics 69(3): 431-67.

Restrepo, F., and G. Subramanian. The new look of deal protection. Stanford Law Review 69(4) (2017). [Forthcoming]

Rossi, S., and P.F. Volpin. 2004. Cross-country determinants of mergers and acquisitions. Journal of Financial Economics 74 (2): 277-304.

Saulsbury, A.O. 2012. The availability of takeover defenses and deal protection devices for Anglo-American target companies. Delaware Journal of Corporate Law 37: 115-148.

Takeover Panel. 2010a. Consultation paper issued by the Code Committee of the Panel Review of certain aspects of the regulation of takeover bids (PCP 2010/2). June 1, 2010.

Takeover Panel. 2010b. Review of certain aspects of the regulation of takeover bids Statement (RS 2010/22). October 21, 2010.

Takeover Panel. 2011a. Consultation paper issued by the Code Committee of the Panel Review of certain aspects of the regulation of takeover bids - Proposed amendments to the Takeover Code (PCP 2011/1). May 27, 2011.

Takeover Panel. 2011b. Review of certain aspects of the regulation of takeover bids Response statement by the Code Committee of the Panel following the consultation on PCP 2011/1 (RS 2011/1). July 21, 2011.

Schwartz, A. 1986. Search theory and the tender offer auction. Journal of Law, Economics, and Organization 2(2):229-53.

Skeel, D. Icarus in the Boardroom: The Fundamental flaws in Corporate America and where they came from (Oxford University Press, 2006).

Strine, L.E. 2015. The Soviet Constitution problem in comparative corporate law: Testing the proposition that European corporate law is more stockholder focused than U.S. corporate law. University of Pennsylvania, Institute for Law \& Economics Research Paper No. 15-30. 